\title{
高次炭化水素燃料を用いた水蒸気改質器による水素製造*
}

篠木俊雄 ${ }^{1}$, 片岡福太郎 $*^{2}$, 藤本泰貴 $*^{3}$ 谷川博哉 $*^{4}$ ，舟木治郎 $*^{5}$ ，平田勝哉 $*^{5}$

\section{Hydrogen Production by a Reactor for Heavy Hydrocarbons}

\author{
Toshio SHINOKI, Fukutarou KATAOKA, Yasutaka FUJIMOTO \\ Hirochika TANIGAWA, Jiro FUNAKI and Katsuya HIRATA*5
}

${ }^{* 5}$ Department of Mechanical Engineering, Doshisha Univ., 1-3, Miyakodani, Tatara, Kyotanabe, Kyoto, 610-0321 Japan

The authors develop a small and simple steam-reforming reactor in a home-use size for $n$-dodecane as a heavy-hydrocarbons fuel. Under such a well-controlled condition by a thermal diffuser as the reactor satisfies two target-temperature criteria, the authors measure the inside-temperature profile and the hydrogen-molecule ratio (concentration) $R_{\mathrm{H} 2}$, together with the molecule ratios $R_{\mathrm{CH} 4}, R_{\mathrm{CO}}$ and $R_{\mathrm{CO} 2}$ of other main gass components such as $\mathrm{CH}_{4}, \mathrm{CO}$ and $\mathrm{CO}_{2}$, respectively. In addition, the authors conduct theoretical calculations, as well as experiments. As a result, the authors successfully achieve suitable inside-temperature profiles. The effects of the steam-to-carbon molar ratio $S / C$ upon $R_{\mathrm{H} 2}, R_{\mathrm{CH} 4}, R_{\mathrm{CO}}$ and $R_{\mathrm{CO} 2}$ are shown, experimentally and theoretically. The experimental results agree well with the theoretical ones. Besides, both carbon balance and conversion ratio show high accuracy in experiments.

Key Words : Steam Reforming, Fuel Cell, $n$-Dodecane, Heavy Hydrocarbon, Hydrogen

\section{1. 緒言}

環境に優しいエネルギー変換装置の一つとして, 燃料電池が注目を集めている. 燃料電池反応に必要な水素 $\left(\mathrm{H}_{2}\right)$ については, 炭化水素 $\left(\mathrm{C}_{n} \mathrm{H}_{m}\right)$ を燃料として, 水蒸気改質反応させ生成する方法が，一般的である. 水蒸気改質反 応は, 部分酸化反応やオートサーマルなど他の方法と比べて, 水素生成効率が高い. よって, メタノールやメタ ンの水蒸気改質反応が，様々な産業分野で，利用されている.

国内で，供給インフラが整っている燃料としては，都市ガス，LPG，ガソリン，軽油，灯油などがある．この うち, 都市ガスの改質反応については，様々な研究開発がなされてきた。一方，ガソリンや軽油，灯油などの高 次炭化水素は, 常温では液体であり, 扱う上で利点がある. しかし, 含有硫黄による触媒活性低下（被毒）や, カーボン（スス）が析出しやすいことなどの欠点がある.

高次炭化水素の液体燃料を使用した改質器の研究としては, Suzuki et al. ${ }^{(1)}$, Fukunaga et al. ${ }^{(2)}$, Kobori et al. ${ }^{(3)}$, 齋 藤と氣仙 ${ }^{(4)}$, Liu et al.$^{(5)}$, Koseki ${ }^{(6)}$, Muramoto et al. ${ }^{(7)}$, Yoon et al..$^{(8)}$ の研究がある.これまで, 高次炭化水素燃料の改質 については, 触媒自体の化学的研究, および, システム全体の理想状態での理論シミュレーションによる評価が, 主に行われてきた。しかし，実際の改質器については，あまり詳細に知られていない.

そこで, 著者らは, 灯油等への応用を想定した基礎研究として, 脱硫の必要がない $n$-ドデカン $\left(\mathrm{C}_{12} \mathrm{H}_{26}\right)$ を燃料と した小形改質器を試作してきた ${ }^{(9)}$-(11). 本研究では, これまでの研究を踏まえ, より正確かつ任意の温度分布の形 成が温度拡散器やガス・バーナの調整により可能な装置を新たに試作寸る。この装置により, 触媒層の目標温度 条件（触媒層上流部で $673 \mathrm{~K}$, 触媒層下流部で $973 \mathrm{~K}$ とする. 前者については沸点とカーボン析出とを, 後者に ついては熱平衡理論(12)を考慮した。）を実現する。その充分に制御された温度条件下で, 改質ガスの各成分濃度 の計測を実施する．そして，熱平衡理論に基づく解析を行い，その結果と実験值とを比較する. 更に，スチーム・ カーボン比によるカーボン・バランスおよび転化率への影響を調べる.

\footnotetext{
*原稿受付 2010 年 9 月 1 日

${ }^{* 1}$ 正員，三菱電機(株) ( ⿳6661-8661 兵庫県尼崎市塚口本町 8-1-1)

${ }^{* 2}$ 同志社大学大学院 工学研究科 機械工学専攻（广610-0321 京都府京田辺市多々羅都谷 1-3)

*3 学生員, 同志社大学大学院 工学研究科 機械工学専攻 ( = $610-0321$ 京都府京田辺市多々羅都谷1-3)

${ }^{* 4}$ 正員, 舞鶴工業高等専門学校（广625-8511 京都府舞鶴市白屋234）

*5 正員, 同志社大学 理工学部 (T610-0321 京都府京田辺市多々羅都谷1-3)
}

E-mail:khirata@mail.doshisha.ac.jp 


\section{2. 実験方法}

\section{$2 \cdot 1$ 実験装置}

本実験装置の概略を, 図 1 に示す，ポンプ(1)から水を供給する. 次に，その水を，ポンプ(2)から供給する $n$ ドデカンと，混合部(3)で混合する．気化部(4)で，その混合物を完全に気化する。二重管(5)(6)の間に，改質触媒(7) (外径 $3 \mathrm{~mm}, 720 \mathrm{cc}, 790 \mathrm{~g}$ ) を充填し，加熱する．熱源には，電気ヒータ(8)と，ガス・バーナ(9)（総発熱量 $1.1 \mathrm{~kW})$ を使用する. ガス・バーナ出力を調整し, 改質反応が充分進行する約 $973 \mathrm{~K}^{(12)}$ まで触媒を温める. 温度 計測は，K型シース熱電対(11)を用いる．改質器から出たガスは，水上置換装置(12)を通り，同時に冷却装置(13) で泠却される，ここで，擬縮液体を回収する．次に，脱水装置(14)に通し，濃度分析計（ガス・クロマトグラフ） と流量計(15)で，各種ガス成分の濃度と総流量を計測する。

\section{$2 \cdot 2$ 改質器内の温度測定}

触媒充填層内の温度分布制御は，改質反応で最も重要な技術である，その理由としては，先に述べたカーボン 析出防止の他に，反応の効率化も挙げられる．温度管理は，触媒層上流部と下流部とで，特に重要になる．すな わち，触媒層上流部の温度はカーボン析出防止と液体燃料の完全気化に影響を与え，下流部の温度は触媒寿命に 影響を与える.

所望の温度分布を実現するため, 温度拡散器の位置 $h(=60 \mathrm{~mm})$ とガス・バーナの位置 $H(=0 \mathrm{~mm})$ の適正条件を, 予備実験を実施し決定した. 温度計測点の詳細を, 図 2 に記す. 改質器内の温度分布計測は, 触媒充填層上流端 $(z$ $=245 \mathrm{~mm})$ の $15 \mathrm{~mm}$ 直下点 $\mathrm{I}$ ，および，下流端 $(z=65 \mathrm{~mm})$ の $15 \mathrm{~mm}$ 直上点 $\mathrm{VI}$ ，点 $\mathrm{I}$ と点 VI との間を $30 \mathrm{~mm} の$ 間 隔で五等分した四点 II-Vの, 計六点で実施する.

主要な実験では, 予定する $S / C$ に応じて改質器を予熱して, $T_{\mathrm{VI}}$ が約 $873 \mathrm{~K}$ になったときに, 水の供給を開始す る. その後, 電気ヒータとガス・バーナを調節して, 充分な時間を経て, $T_{\mathrm{VI}}$ を $973 \pm 50 \mathrm{~K}$ に安定させる. その後, 水に加えて, $n$-ドデカン $Q_{\mathrm{d}}=4.0 \mathrm{cc} / \mathrm{min}$ も流し始める. ここに, 時間 $t$ とは, $n$-ドデカン投入開始からの時間とす る. 通常, $n$-ドデカン投入直後, $T_{\mathrm{I}}$ は上昇し, $T_{\mathrm{II}}-T_{\mathrm{VI}}$ は下降するので, $S / C$ や $L H S V$ の值にもよるが, 所定の 目標温度条件を達成するために, 電気ヒータとガス・バーナからの供給熱量を再調整する. この調整は $t<900$ $\mathrm{s}$ で実施する。ここに，目標温度条件とは，前述した通り， $T_{\mathrm{I}}=673 \mathrm{~K}$ かつ $T_{\mathrm{VI}}=973 \mathrm{~K}$ である.

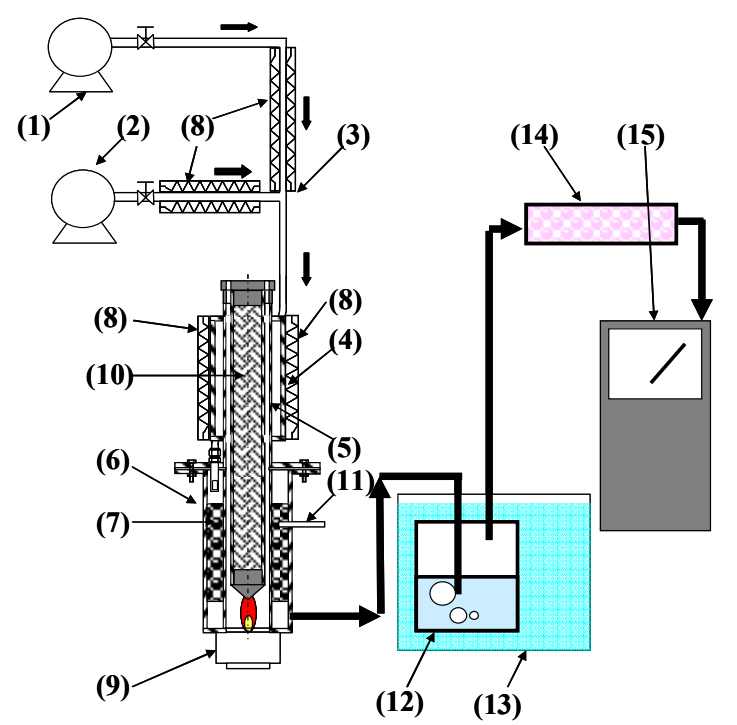

Fig. 1. Experimental apparatus. (1) Pump for water, (2) pump for fuel, (3) mixer, (4) vaporisation unit, (5) inner pipe, (6) outer pipe, (7) catalyst, (8) electric heater, (9) gas burner, (10) thermal diffuser, (11) sheathed thermocouple, (12) cold trap, (13) cooling system, (14) dryer, (15) gas chromatograph and flowmeter.

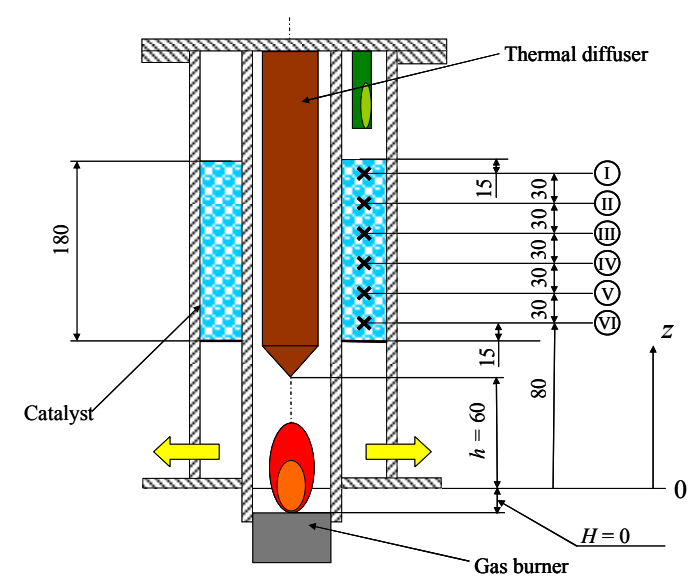

Fig. 2. Close-up view of a reactor, together with a coordinate system and temperature-measurement positions. 
本研究では, 目標温度条件の他に，改質器内の温度制御に関して，二つの規定を設けている，一つ目の規定で は， $T_{\mathrm{I}}$ が $673 \mathrm{~K}$ に達したとき，実験を停止する（規定 $\alpha$ と呼称）。なぜならば， $T_{\mathrm{I}}>673 \mathrm{~K} て ゙ は ， n$-ドデカンが

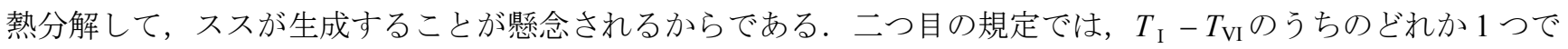
も $1073 \mathrm{~K}$ を超えて高温になったとき，実験を停止する（規定 $\beta$ と呼称）。これは，装置自体の耐熱性の問題およ び触媒のシンタリングが危惧されるためである.

\section{$2 \cdot 3$ 改質ガスの主要成分濃度の計測}

改質ガス主要成分の濃度計測には, ガス・クロマトグラフ（島津製作所製 GC-3BT）を使用する．カラムはパ ックド・カラム (SHINCARBON ST, $2 \mathrm{~m} \times 3 \mathrm{~mm} \phi$ ，ステンレス製）を二本使用する. また，カラム温度は $358 \mathrm{~K}$ で一定とし，試料注入量は $0.5 \mathrm{ml}$ とする。キャリア・ガスとしては，アルゴン・ガスを用いる.

\section{3. 結果と考察}

\section{$3 \cdot 1$ 改質器内の温度分布}

図 3 は， $n$-ドデカンを投入後， $1800 \mathrm{~s} ， 3600 \mathrm{~s} ， 5400 \mathrm{~s}$ の時間が経過し，安定したときの，触媒充填層内の温度 分布の一例を示す. すなわち, $S / C=4, L H S V=0.33 \mathrm{~h}^{-1}, Q_{\mathrm{w}}=15.2 \mathrm{cc} / \mathrm{min}, Q_{\mathrm{d}}=4.0 \mathrm{cc} / \mathrm{min}$ のときの, $t=1800 \mathrm{~s}$, $3600 \mathrm{~s}, 5400 \mathrm{~s}$ での結果を示す. 図 3 は通常の実験結果の一例であり, $t<0$ と $t>0$ とで水の流量を一定とし, か つ, $t=0-900 \mathrm{~s}$ で電気ヒータとガス・バーナの供給熱量を調節している.

$t=1800 \mathrm{~s} ， 3600 \mathrm{~s} ， 5400 \mathrm{~s}$ の結果は良く一致する．つまり，t=1800 s でも，時間によらず，触媒充填層内の温 度は充分安定している. よって, 以降の実験では $t=3600 \mathrm{~s}$ のみ考える. 更に詳しく見る. (1)温度の流下方向 への直線状の単調増加傾向, (2)目標温度条件の達成, (3)規定 $\alpha$ と $\beta$ の満足などの特徵を, 確認できる.

\section{$3 \cdot 2$ 熱平衡理論を用いた計算}

図 4 は, 水蒸気改質反応 ${ }^{(9)} に よ り$ 生成する $\mathrm{H}_{2}, \mathrm{CO}_{2}, \mathrm{CO}, \mathrm{CH}_{4}$ の生成量を熱平衡理論より計算した結果である. すなわち, $S / C=3,5$ における, 様々な反応温度 $T$ に対する各成分濃度 $R_{\mathrm{H} 2}, R_{\mathrm{CO} 2}, R_{\mathrm{CO}}, R_{\mathrm{CH} 4}$ を示す.

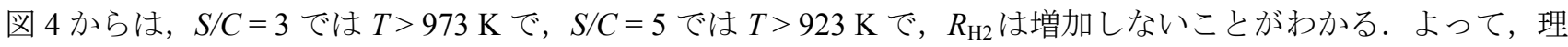
論計算からは $n$-ドデカンの水蒸気改質に, $T \approx 973 \mathrm{~K}$ が適正であると考えられる.

\section{$3 \cdot 3$ ガス・クロマトグラフによる各成分濃度の測定}

図 5 は，ガス・クロマトグラフを用いて， $L H S V=0.33 \mathrm{~h}^{-1}, Q_{\mathrm{d}}=4.0 \mathrm{cc} / \mathrm{min}, T_{\mathrm{VI}}=973 \mathrm{~K}, t=3600 \mathrm{~s}$ で, 改質ガ スの各成分濃度を測定した結果である. 主要なガス成分濃度 $R_{\mathrm{H} 2}, R_{\mathrm{CH} 4}, R_{\mathrm{CO}}, R_{\mathrm{CO} 2} へ$ $S / C$ の影響を示している. 比 較の為, $T=973 \mathrm{~K}$ での理論值を四種類の線分で, Suzuki et al. (2000) ${ }^{(1)}$ の灯油に関する実験值を中実記号で示す. なお， $S / C=2$ で実験を行ったところ, $n$-ドデカンが炭化して，触媒にススが付着した．よって, $S / C \leq 2$ での実験 結果は, 示していない.

まず， $S / C=3,5$ で，本結果を Suzuki et al.と比較する. $R_{\mathrm{H} 2}, R_{\mathrm{CH} 4}, R_{\mathrm{CO}}, R_{\mathrm{CO} 2}$ 全てが良く一致し，今回の実験精度 の高さが確認できる. 次に $S / C$ の影響を考える. $R_{\mathrm{H} 2}$ は, $S / C$ の増加につれて増加傾向を示すが, その值はほぼ $70 \%$ 程度である，その他の成分については， $R_{\mathrm{H} 2}$ よりずっと小さい，すなわち， $R_{\mathrm{CO} 2}$ は $20 \%$ 程度であり， $R_{\mathrm{CH} 4}$ と $R_{\mathrm{CO}}$ は常にそれぞれ $5 \%, 10 \%$ 以下である.さらに細かく見ると， $S / C$ の増加につれて， $R_{\mathrm{CO} 2}$ は僅かに増加し， $R_{\mathrm{CO}}$ と $R_{\mathrm{CH} 4}$ は僅かに減少する.

実験值を理論值と比較すると，上述の四つの成分濃度は定性的にも定量的にも良好な一致を示す．ただし，細 かく見ると， $R_{\mathrm{H} 2}$ の実験值と理論值との差異は， $S / C$ の増加に伴い若干の減少傾向を示す．この点は， $R_{\mathrm{CH} 4}$ の実験 值と理論值との差異が， $S / C$ の増加に伴う減少傾向を示すことと, よく対応する. また, 他の成分濃度について も実験值と理論値との差異は, $S / C$ の増加に伴い若干の減少傾向を示す. 次節で議論する転化率に関する結果も, $S / C$ 増加に伴うこのような差異の減少傾向とよく整合する。この様な差異の減少傾向は, 投入する $n$-ドデカンと 水との不完全な混合が $S / C$ が大きくなるにつれて解消することに関係すると考えられる. 


\section{$3 \cdot 4$ 改質ガスのカーボン・バランス誤差と転化率}

図 6 にカーボン・バランス誤差 $C B E[\%]$ と転化率 $X_{\mathrm{C} 12 \mathrm{H} 26}$ [\%]の測定結果を示す.すなわち，図 6 は $L H S V=0.33$ $\mathrm{h}^{-1}, Q_{\mathrm{d}}=4.0 \mathrm{cc} / \mathrm{min}, T_{\mathrm{VI}}=973 \mathrm{~K}, t=3600 \mathrm{~s}$ での様々な $S / C$ に対する, $C B E$ (図中苗) と $X_{\mathrm{C} 12 \mathrm{H} 26}$ (図中 ) を示す.

まず, $C B E$ を考える. $C B E$ は $S / C$ によらず，常に $10 \%$ 以下である.このことは，主要な四種類のガス $\mathrm{H}_{2}$, $\mathrm{CH}_{4}, \mathrm{CO}, \mathrm{CO}_{2}$ 以外の成分が，少ないことを示す.

次に， $X_{\mathrm{C} 12 \mathrm{H} 26}$ を考える. $S / C<4$ において $X_{\mathrm{C} 12 \mathrm{H} 26}$ は $83 \%$ ある。.しかし， $S / C \geq 4$ において $X_{\mathrm{C} 12 \mathrm{H} 26}$ は常に 90 \%程度を示し, $S / C$ の影響はほとんどない. $X_{\mathrm{C} 12 \mathrm{H} 26}$ が， $S / C<4.0$ で，より低い值を示寸原因の一つとして， $n$-ドデカンと水蒸気の混合が完全ではないことが挙げられる.つまり, 混合不完全の為, 蒸発後の濃度にも 偏りが生じ，理論通りの反応から乘離することが考えられる.

以上より，設計も含めた条件を考えると $n$-ドデカンの水蒸気改質では $S / C \geq 4.0$ が妥当と思われる. しか し，実務的観点からは， $S / C$ が大きくなると，導入する水蒸気の量が大きくなる.このため，水蒸気発生に過剩 な熱量が必要となることから, 総エネルギー損失が増大寸る.よって, 今回の実験結果より, 実機を考慮すると, $S / C=4.0$ 程度を運転条件とすることが望ましいとの結論を導ける.

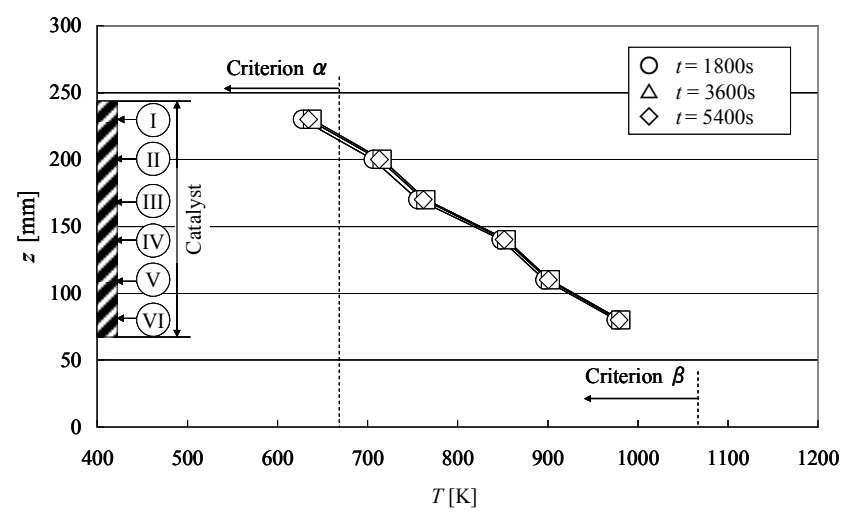

Fig. 3. Time development of the temperature profile inside a catalyst-layer bed $\left(S / C=4, L H S V=0.33 \mathrm{~h}^{-1}, Q_{\mathrm{w}}\right.$ $\left.=15.2 \mathrm{cc} / \mathrm{min}, Q_{\mathrm{d}}=4.0 \mathrm{cc} / \mathrm{min}\right)$.

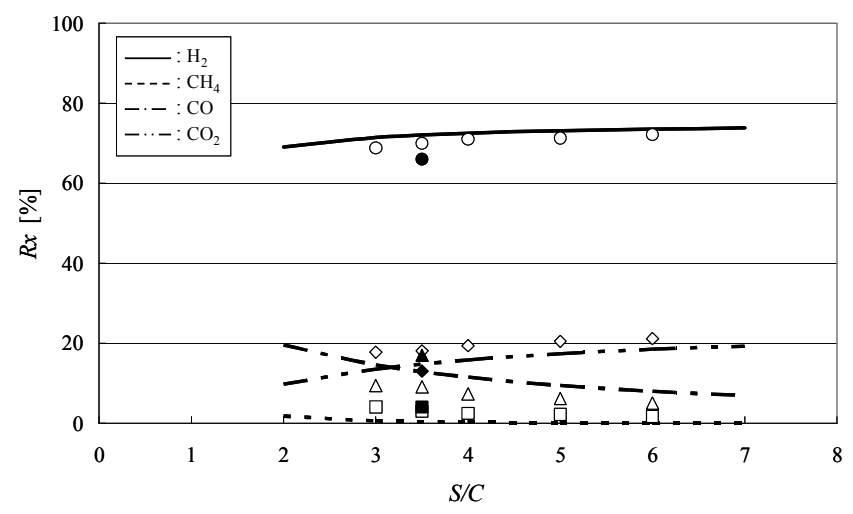

Fig. 5. Molecule ratio $R_{x}$ by experiments versus steam-to-carbon molar ratio $S / C\left(L H S V=0.33 \mathrm{~h}^{-1}, Q_{\mathrm{d}}=\right.$ $\left.4.0 \mathrm{cc} / \mathrm{min}, T_{\mathrm{VI}}=973 \mathrm{~K}, t=3600 \mathrm{~s}\right)$. $\bigcirc$ and, $\mathrm{H}_{2}$; $\square$ and $\boldsymbol{\square}, \mathrm{CH}_{4} ; \triangle$ and $\boldsymbol{\Delta}, \mathrm{CO} ; \diamond$ and $\diamond \mathrm{CO}_{2}$. $\bigcirc, \square, \triangle$ and $\diamond$, The present; $\bigcirc, \boldsymbol{\square}, \boldsymbol{\Delta}$ and $\diamond$, Suzuki et al., $2000(S / C=3.5, T=1173 \mathrm{~K})$. Lines denote the thermal-equilibrium theory.

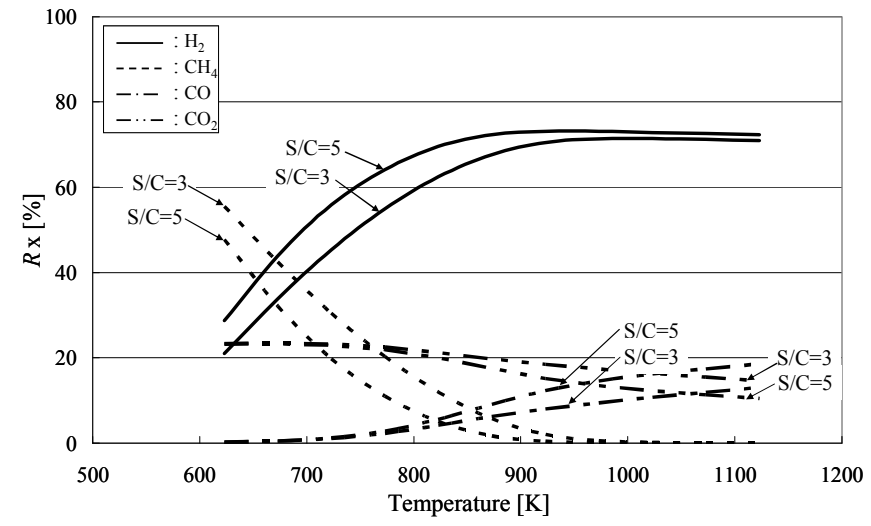

Fig. 4. Molecule ratio $R_{x}$ predicted by the thermal-equilibrium theory versus reaction temperature $T$ $(S / C=3,5)$.

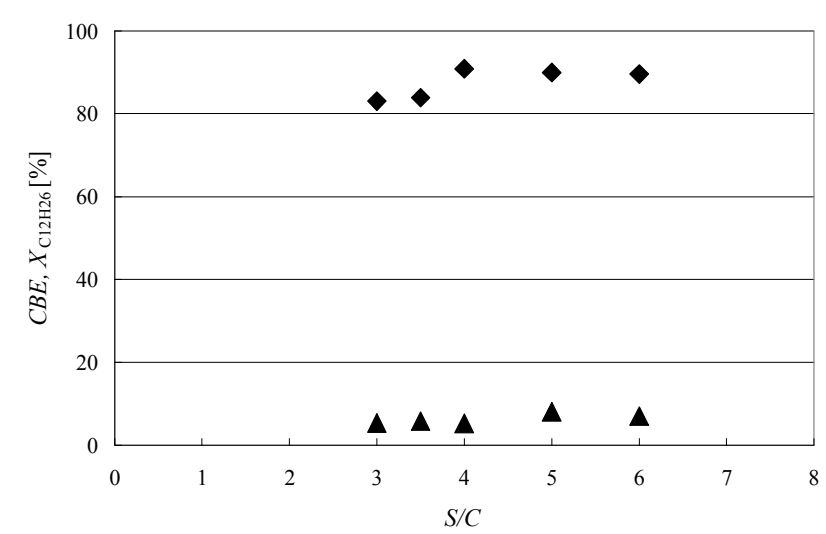

Fig. 6. Carbon-balance error $C B E$ and conversion ratio $X_{\mathrm{C} 12 \mathrm{H} 26}$ versus steam-to-carbon ratio $S / C(L H S V=0.33$ $\left.\mathrm{h}^{-1}, Q_{\mathrm{d}}=4.0 \mathrm{cc} / \mathrm{min}, T_{\mathrm{VI}}=973 \mathrm{~K}, t=3600 \mathrm{~s}\right) . \boldsymbol{\Delta}, C B E$,

$\checkmark, X_{\mathrm{C} 12 \mathrm{H} 26}$. 


\section{4. 結言}

今回，ガソリンや軽油，灯油など常温液体の高次炭化水素燃料の水素製造に関する基礎研究を実施した。代表 的な高次炭化水素として, $n$-ドデカンを燃料として用いて, 実用規模の改質反応器を試作し, 所定の温度条件を 満足させることに成功した. そのもとで, 反応性能すなわち水素をはじめとする主要ガス成分の濃度を評価した. 理論と実験結果とは, よい一致を示した. 更に, カーボン・バランス誤差と転化率への $S / C$ 効果も明らかにした. 理論的には，更に $R_{\mathrm{H} 2}$ を高めることは可能であり，今後の更なる研究が望まれる．また，システム全体の熱効率 を考えると， $S / C$ をできるだけ理論值 2 に近づけるべきだと考えている. その為には, 水と燃料のより一様な混 合を検討することが必要と思われる.

\section{文献}

(1) T. Suzuki, H. Iwami and T. Yoshinari, "Steam reforming of kerosene on $\mathrm{Ru} / \mathrm{Al}_{2} \mathrm{O}_{3}$ catalyst to yield hydrogen," International Journal of Hydrogen Energy, 25, pp. 119-126, 2000.

(2) T. Fukunaga, H. Katsuno, H. Matsumoto, O. Takahashi and Y. Akai, "Development of kerosene fuel processing system for PEFC," Catalysis Today, 84, pp. 197-200, 2003.

(3) Y. Kobori, T. Matsumoto, I. Anzai, S. Ueno and Y. Oishi, "Kerosene reforming catalyst for fuel cell application -kinetic and modeling analysis of steam reforming-," Science and Technology in Catalysis 2002, Kodansha Ltd., pp. 477-478, 2003.

（4）齋藤一仁，氣仙忠，“灯油型燃料電池用水素製造技術の開発”，出光技報，46(1), pp. 51-57, 2003.

(5) D. J. Liu, D. Kaun, H. K. Liao and S. Ahmed, "Characterization of kilowatt-scale autothermal reformer for production of hydrogen from heavy hydrocarbons," International Journal of Hydrogen Energy, 29, pp. 1035-1046, 2004.

(6) H. Koseki, "Flame stability limit and exhaust emissions of low calorific fuel combustion in turbulent diffusion combustor for a small-scale fuel cell," JSME International Journal, 47(2), pp. 221-227, 2004.

(7) T. Muramoto, K. Nariai, H. Ohara and H. Kamata, "Durability of $\mathrm{Ru} / \mathrm{CeO}_{2} / \gamma-\mathrm{Al}_{2} \mathrm{O}_{3}$ catalyst for steam reforming of dodecane," Journal of the Japan Petroleum Institute, 52(3), 108-113, 2009.

(8) S. Yoon, J. Bae, S. Kim and Y. S. Yoo, "Self-sustained operation of a $\mathrm{kW}_{\mathrm{e}}$-class kerosene-reforming processor for solid oxide fuel cells,” Journal of Power Sources, 192, pp. 360-366, 2009.

（9）谷川和哉，篠木俊雄，谷川博哉，舟木治郎，平田勝哉，“燃料電池向け高次炭化水素水蒸気改質器のための基礎研 究”，第十二回動力・エネルギー技術シンポジウム講演論文集, pp.269-274, 2007.

(10) 片岡福太郎, 篠木俊雄, 谷川和哉, 谷川博哉, 舟木治郎, 平田勝哉, “重炭化水素燃料の水蒸気改質反応について”, 第十三回動力・エネルギー技術シンポジウム講演論文集, pp.265-268, 2008.

(11) 片岡福太郎, 篠木俊雄, 石田真一, 谷川博哉, 舟木治郎, 平田勝哉, “燃料電池向け $n$-ドデカン水蒸気改質の基礎 研究”，第十四回動力・エネルギー技術シンポジウム講演論文集，pp.469-472, 2009.

(12) 松本寛人，“灯油からの高濃度水素製造技術”，水素利用技術集成，NTS, Tokyo, pp. 120-137, 2003. 